\title{
Erzincan İli 110 Acil Çağrılarının Coğrafi Bilgi Sistemleri ve Farklı İstatistiksel Analiz Yöntemleri ile Değerlendirilmesi
}

\author{
Mehmet Oğuzhan GÜREL ${ }^{1}$, Halim Ferit BAYATA², Osman Ünsal BAYRAK³
}

\section{Özet}

110 Acil çağrıları için en önemli verimlilik ölçütü, acil yardım çağrısının yapılmasından sonra ekiplerin olay yerine ulaşması ile acil müdahalenin başlatılmasına kadar geçen ve "müdahale süresi" olarak adlandırılan zamandır. Müdahale süresini etkileyen en önemli sorunlardan biri istasyon yerleşim yerinden kaynaklanan sıkıntılardır. Günümüzde ileri bilgi teknolojileri ve görüntüleme yöntemleri istasyon yerleşim alanı belirlenmesi çalışmalarında yaygın olarak kullanılmaktadır. Bu amaçla kullanılan bilgi teknolojilerinden biri de "Coğrafi Bilgi Sistemleri" (CBS)'dir. Literatür incelendiğinde, Türkiye'de bulunan çeşitli illerde istasyon yerleşim yeri belirleme çalışmalarının CBS kullanılarak yapıldığı görülmüştür. Bu çalışmada, Erzincan Merkez 110 itfaiye istasyonlarının aldığı çağrılardan hareketle mevcut istasyon yerlerinin kapsayıcılığının belirlenmesi için CBS'nin ve çağrıların modellenmesi için zaman serileri ve yapay sinir ağlarının kullanılması amaçlanmıştır. Mevcut araştırma Erzincan merkezin mahallelerini kapsamakta olup, veriler Erzincan Belediyesi İtfaiye Müdürlüğünden alınmıștır. Verilerin analizinde SPSS (Sosyal Bilimler İçin İstatistik Programı) paket programı, MATLAB programı ve ArcGIS programı kullanılmıştır. Verilerin ArcGIS'de sorgulanabilmesi için öncelikle temel coğrafi veri (harita) altlıkları oluşturulmuştur. Ardından veriler aynı koordinat sistemi içerisinde sayısallaştırılarak ArcGIS programına aktarılmıștır. Araştırmanın sonucunda CBS'nin konumsal analiz fonksiyonları ile itfaiye istasyonları için en uygun yerler önerilmiştir.

Anahtar Kelimeler: İtfaiye İstasyonu, 110 Acil, Coğrafi Bilgi Sistemleri, Konumsal Analiz

\footnotetext{
1 Öğretim Görevlisi, Mimarlık ve Şehir Planlama Bölümü, İliç Dursun Yıldırım MYO, Erzincan Binali Yıldırım Üniversitesi, Erzincan İlgili yazar e-posta/ Corresponding author e-mail: oguzhan.gurel@erzincan.edu.tr ORCID No: 0000-0001-9988-9169

${ }^{2}$ Dr. Öğr. Üyesi, İnşaat Mühendisliği Bölümü, Erzincan Binali Yıldırım Üniversitesi, Erzincan e-posta/e-mail: hfbayata@erzincan.edu.tr ORCID No: 0000-0001-8274-8888

${ }^{3}$ Dr. Öğr. Üyesi, İnşaat Mühendisliği Bölümü, Atatürk Üniversitesi, Erzurum

e-posta/e-mail: unsalb@atauni.edu.tr ORCID No: 0000-0003-4039-1248
}

Bu makaleye atıf yapmak için- To cite this article Gürel, M. O., Bayata, H. F. ve Bayrak, O. Ü. (2020). Erzincan İli 110 Acil Çağrılarının Coğrafi Bilgi Sistemleri ve Farklı İstatistiksel Analiz Yöntemleri ile Değerlendirilmesi. Afet ve Risk Dergisi, 3(2), 236 - 255. 


\title{
Evaluation of 110 Emergency Calls of Erzincan with Geographical Information Systems and Modeling with Different Statistical Analysis Methods
}

\begin{abstract}
The most important criterion for 110 emergency call is the time, which is between the arrival of the teams at the event location after the emergency call and the initiation of emergency response; and called as "response time". One of the most important problems affecting the intervention time is the problems arising from the station settlement. Today, advanced information technologies and imaging methods are widely used in the determination of the station settlement area. One of the methods used for this purpose is "Geographic Information Systems" (GIS). In the literature, various station settlement determination process in Turkey have been seen in the CBS. In this study, it is aimed to use time series and artificial neural networks to model the geographic information systems and calls to determine the coverage of the existing station locations based on the calls received by the 110 fire stations in Erzincan city center. The current research covers the neighborhoods of Erzincan center and the data were taken from the Erzincan Municipality Fire Department. SPSS (Statistical Package for the Social Sciences) package program, MATLAB program and ArcGIS program were used to analyze the data. In order to query the data in ArcGIS, basic geographical data (map) bases were created. Then, the data were digitized in the same coordinate system and transferred to the ArcGIS program. At the end of the research, the most appropriate the fire station were recommended with the locational analysis functions of GIS.
\end{abstract}

Keywords: Fire Station, 110 Emergency, Geographical Information Systems, Spatial Analysis

\section{GİRİ̧}

İnsanların yaşamını tehdit eden sağlık sorunu, deprem, heyelan, sel ve taşkın, kuraklık, yangın, endüstriyel kazalar, ev, iş ve trafik kazaları, terör saldırıları vb. gibi birçok olay acil durum olarak kabul edilmektedir (Öztürk, vd., 2013). Acil tedavi gerektiren hastalık, söndürülmeyi bekleyen bir yangın, güvenlik birimlerinin müdahalesini gerektiren bir durum sonucu ölüm veya kalıcı rahatsızlık hallerinin ortaya çıkma olasılığı müdahale zamanı ile yakından ilişkilidir. Acil müdahalelerde birkaç saniyelik gecikme dahi hayat, sağlık ve para kaybı ile sonuçlanabilir. $\mathrm{Bu}$ nedenle "müdahale süresi" acil durum hizmetleri için önemli bir performans ölçütüdür (Pasha, 2006). Müdahale süresinin en aza indirgenmesi için araç ve istasyon sayısının arttırılması gibi işlemler mali yük getirecek öneriler arasında bulunmaktadır. Fakat araç/istasyon sayısının arttırılması genellikle sınırlı hatta çoğu zaman imkansızdır. Bu durumda acil durum araçlarına etkin bir yerleşim yerinin belirlenmesi önem arz etmektedir. Yerleşim yerlerindeki fiziksel, ekonomik, sosyal politikalar, teknoloji, toplumsal olaylar, doğal afetler ve çevresel değişimler ile artan nüfus, ekonomik büyüme, tüketim modelleri ve kazancın değişmesi, endüstrileşme gibi durumlar sonucunda kentlerde dinamik bir yapı oluşmaktadır. Bu değişim ve gelişimden dolayı hayati önem taşıyan acil durum tesislerinin de (itfaiye istasyonları) durağan olmaması ve en uygun yerlerin belirli zamanlarda yeniden düzenlenmesi gerektiği kabul edilmelidir. Böylece can ve mal kaybının en aza indirilmesi ve maksimum fayda elde edilmesi sağlanabilir (Coşkun, 2007).

Acil durum araçlarının en hızlı şekilde olay yerine ulaşarak müdahalede bulunması, ancak bilimsel altyapısı sağlam bir acil yardım hizmetleri sisteminin kurulmasıyla gerçekleşebilir (Selim ve Özkarahan, 2003; Sarhan, vd., 2015). Acil durum istasyonlarının yerini belirlemede çeşitli bilgi teknolojileri ve görüntüleme yöntemleri kullanılmaktadır. Son zamanlarda yapılan çalışmalara 
Erzincan İli 110 Acil Çağrılarının Coğrafi Bilgi Sistemleri ve Farklı İstatistiksel Analiz Yöntemleri ile Değerlendirilmesi

bakıldığında (Erkal ve Değerliyurt, 2013; Swalehe, 2016) Coğrafi Bilgi Sistemleri (CBS) tabanlı analizlerin kullanımının yaygınlaştığı ve yer belirlemede etkili bir araç olduğu görülmektedir (Sarhan, vd., 2015). Mevcut araştırmanın amacına hizmet etmesi için CBS'nin kullanılması uygun görülmüştür.

CBS, kullanıcıların daha doğru karar vermesi, üretimin arttırılması ve böylece zaman, para ve işgücü tasarrufu sağlaması amacıyla, çok sayıdaki mekânsal verinin ve bunlara ilişkin özniteliklerin toplanması, depolanması, sorgulanması, analizi ve sunulması için bir araya getirilmiş bilgisayar yazılımı ve donanımıdır (Aksaraylı, 2005). CBS, kamusal ve özel şirketlere ait tesislerin hizmet verebileceği en uygun yerlerin belirlenmesi açısından büyük önem taşımaktadır. Özel şirketlerin tesis yerleşim problemlerinde (mağaza, fabrika vb.) maliyetin en aza indirilmesi, kamusal tesis yerleşim problemlerinde (itfaiye, hastane, okul vb.) ise nüfusun bu tesise erişebilirliğini sağlamak önem kazanmaktadır (ReVelle ve Eiselt, 2005). Kamusal açıdan yerleşim yeri tespitine ilişkin literatür incelendiğinde; genel olarak en uygun okul yerleri (Uslu, vd., 2017); katı atık depolama bölgeleri (Djokanovic, vd., 2016); toplu konut alanları (Yalçın ve Batuk, 2010); rüzgâr santrallerinin yerleri (Eroğlu, 2014) gibi konularda CBS’nin kullanıldığı görülmektedir. Özel olarak itfaiye istasyonlarına ait literatür incelendiğinde Erden (2009) ve Erden ve Coşkun (2011) tarafından CBS'nin Analitik Hiyerarşi Yöntemi kullanılarak İstanbul iline ait itfaiye istasyonlarının yerlerini belirlemek amacıyla yapılan çalışmada 35 adet mevcut itfaiye istasyonu analize dâhil edilmiştir. Çalışma bölgesi içinde bulunan bu istasyonların uluslararası standart olan 5 dakika erişim zamanını sağlamadığı belirlenmiştir. Chaudhary, vd. (2016) tarafından CBS'nin bir ara yüzü olan Analitik Hiyerarşi Yöntemi kullanılarak Katmandu şehrinin en uygun itfaiye istasyon yerinin belirlenmesi gerçekleştirilmiştir. Yapılan analizde çalışma alanının sadece \%13,46'sının itfaiye istasyon yeri için uygun olduğu belirlenmiştir. Aydın (2018) tarafından yapılan itfaiye istasyonu belirleme çalışmasında uygulama alanı İzmir seçilmiş olup tampon bölge (buffer) analizi yapılarak istasyon yerleri değerlendirilmiştir. İzmir iline ait 808 bölgeden 482 tanesine yeterli hizmet verilemediği tespit edilmiştir. Literatür değerlendirildiğinde elde edilen sonuçlara göre, itfaiye istasyonlarının dağılımlarının genel olarak dengeli olmadığı, istasyonların birbirine yakın olduğu, bazı bölgelerde ise hizmetin yetersiz kaldığı ortaya konulmuştur. Literatürde Erzincan iline ait herhangi bir istasyon yeri belirleme çalışmasına rastlanmamıştır. Ayrıca 2019 yılı itibariyle merkez beldeler Erzincan iline bağlanmıș olup; il merkezine ait nüfus yoğunluğu değişmiştir. Bu nedenle mevcut acil durum istasyon noktalarının değerlendirilmesi ve tekrar en uygun noktaların belirlenmesi önem arz etmektedir. Bu sebeple çalışma kapsamında Erzincan iline ait itfaiye istasyon yerlerinin CBS ile değerlendirilmesi amaçlanmıștır.

\section{MATERYAL VE YÖNTEM}

\subsection{Araștırmanın Yeri ve Özellikleri}

Erzincan, Doğu Anadolu Bölgesi'nin Kuzey Batı bölümünde yukarı Fırat havzasında 3902 - 40 05` kuzey enlemleri ile 38 16`-40 45` Doğu boylamları arasında yer almaktadır (Şekil 1). Erzincan nüfusu 236.034, yüzölçümü $11.903 \mathrm{~km} 2$ 'dir. Tanımlayıcı tipteki bu araştırma Erzincan merkez mahallelerini ve 2019 yerel seçimleriyle beraber merkeze bağlanan Kavakyolu, Çukurkuyu, Yalnızbağ, Ulalar, Akyazı, Yoğurtlu, Geçit, Yaylabaşı beldelerini de kapsayacak şekilde yapılmıştır. Erzincan ilinin Türkiye haritasındaki yeri Şekil 1a'da, merkez ve bağlanan belde sınırlarını gösteren harita Şekil 1b'de verilmiștir. 


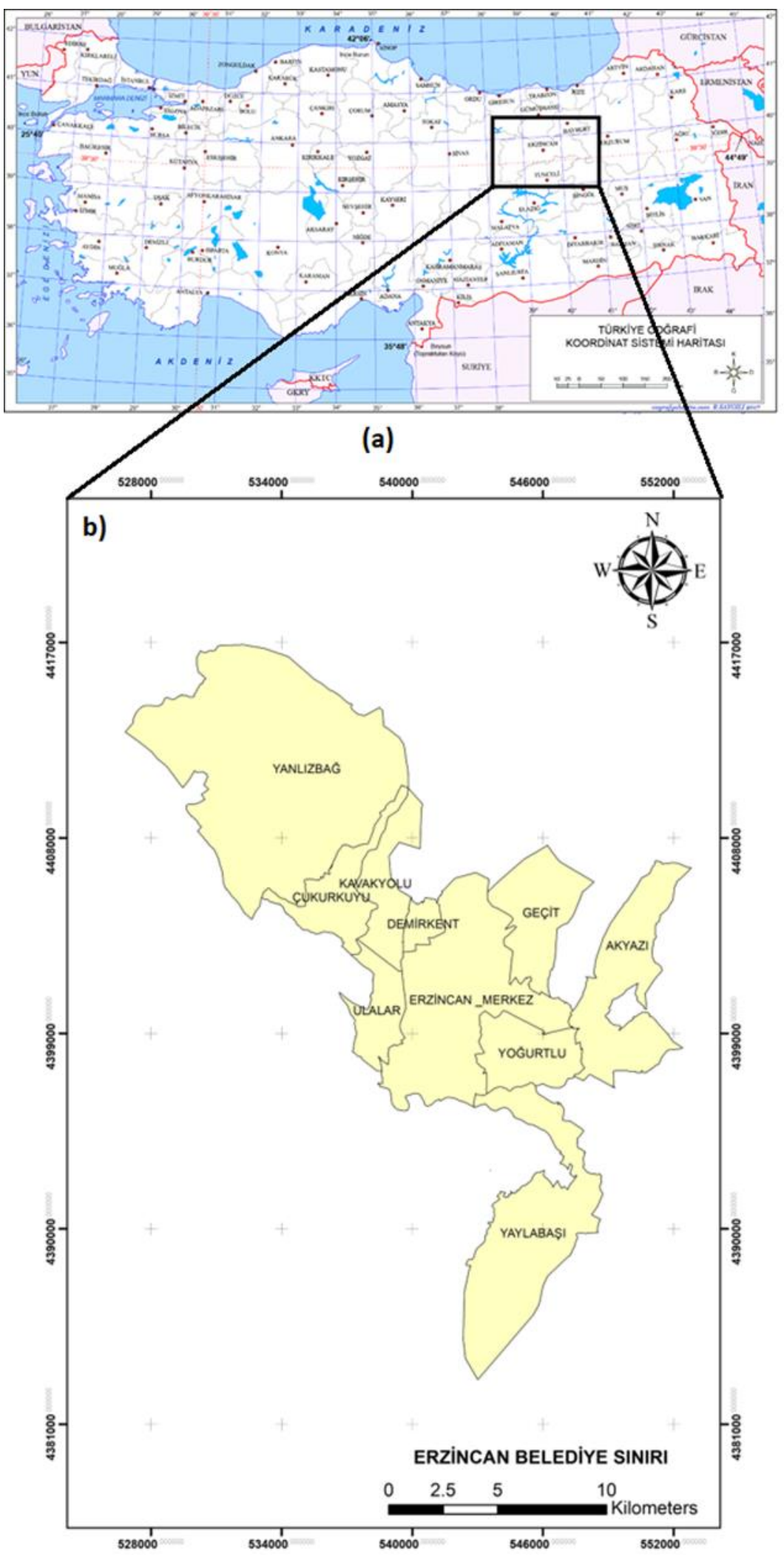

Şekil 1. a) Erzincan ilinin Türkiye haritası üzerindeki konumu, b) Erzincan merkez ve bağlanan belde sinırları 
Erzincan İli 110 Acil Çağrılarının Coğrafi Bilgi Sistemleri ve Farklı İstatistiksel Analiz Yöntemleri ile Değerlendirilmesi

\subsubsection{Erzincan Merkez 110 İtfaiye İstasyonunun Özellikleri}

Erzincan il merkezinde 1 adet 110 itfaiye istasyonu bulunmaktadır. Bu istasyon dahilinde 8 adet itfaiye aracı, 1 adet kaza kurtarma aracı, 1 adet yıkıntıdan kurtarma aracı olmak üzere 10 adet acil müdahale aracı bulunmaktadır. İstasyonda üç ayrı ekip vardiya usulü ile çalışmaktadır. Vardiya ekipleri; 1 . vardiya 13,2 . vardiya 13 ve 3 . vardiya 14 kiși olmak üzere toplam 40 kișilik müdahale ekibi bulunmaktadır. Bunun yanında müdür, müdür yardımcısı, sekreter...vb. gibi idari hizmetlerden sorumlu 10 adet personelle beraber toplam 50 kişi hizmet vermektedir (URL 1). Bütün acil çağrılarda olduğu gibi yangınlarda da hem can hem de mal kaybının önüne geçebilmek için ilk 10 dakikanın önemi çok fazladır. Bu nedenle özellikle merkezde ilk 10 dakika kırsalda ise ilk 30 dakikanın altında bir sürede olaya müdahale edilmesi hedeflenmektedir.

\subsection{Verilerin Toplanması}

$\mathrm{Bu}$ çalışmada kullanılan veriler 01.01.2018-31.12.2018 tarihleri arasındaki 110 itfaiye merkezlerine yapılan çağrıları içermektedir. Erzincan Belediyesi İtfaiye Müdürlüğünden alınan verilerde 2018 yılında meydana gelen yangınlara ait adres, tarih ve yangın türlerine (bina yangını, araç yangını, arazi yangını, çöp yangını ve diğer yangınlar) ait bilgiler yer almaktadır. Toplamda itfaiye merkezinden alınan 387 adet çağrı verisiyle çalıșılma yürütülmüștür. Çalıșmada kullanılan Erzincan merkez mahalle ve bağlanan beldelere ait nüfus verileri ise TÜIIK internet sitesinden temin edilmiştir (URL 2).

\subsection{Verilerin Analizi}

Bu çalışmada veri analizi yöntemi olarak coğrafi bilgi sistemleri, zaman serileri ve yapay sinir ağları kullanılmıștır.

\subsubsection{Coğrafi Bilgi Sistemleri}

Söz konusu sistemde veri analizinde kullanılmak üzere;

- Çalışmanın yapıldığı bölgenin coğrafi harita altlığı (mahalle haritaları) ilgili kurumdan alınıp CBS sistemine girilmiştir.

- Öznitelik verilerinin girileceği veri tabanları oluşturulmuştur.

- Öznitelik verilerinin veri tabanına girişi gerçekleştirilmiştir.

\subsubsection{Grafik Verilerin Sisteme Aktarılması ve Veri Tabanının Olușturulması}

Öncelikle çalışma alanına ilişkin mahallelere ait coğrafi harita altlı̆̆ı, 110 itfaiye çağrılarına ait veriler ve istasyonların yerleșim yerlerine ait mekânsal veriler CBS sistemine vektörel veriler olarak aktarılmıştır. Vektörel verilerin; alan, hat ve nokta özellikleri tanımlanıp uygun altyapıya sahip bir veri tabanı oluşturulmuştur. Verilerin ArcGIS ortamında kullanılabilmesi için öncelikle temel coğrafi veri (harita) oluşturulmuştur. Bu harita; Erzincan iline 2019 yerel seçimleriyle bağlanan beldeleri ve merkezde yer alan mevcut mahalle sınırlarını kapsamaktadır. Bu veriler mevcut koordinat sistemiyle sayısallaştırılarak ArcGIS (versiyon 10.4.1) programına aktarılmıştır

Erzincan Belediyesi İtfaiye Müdürlügünden alınan veriler, Excel ortamında ihtiyaç olmayan bilgilerden arındırılarak veri tabanı için kullanılabilir şekilde düzenlenmiştir. Analizlerde kullanılmak üzere Erzincan Belediyesi İtfaiye Müdürlüğüne gelen yangın türleri (baca yangını, araç yangını, arazi yangını, vb.) ve mahalleler göre gelen yangın çağrı sayıları gibi bilgiler içeren Excel tabloları oluşturulmuştur. Çalıșmada kullanılan vakalar mahalleler baz alınarak düzenlenmiştir.

\subsubsection{Buffer (Tampon) ve Intersect Analizi}

Buffer analizleri bir nokta, poligon veya çizgi şeklindeki grafik verilerin etrafında istenilen genişlikte bir bölgenin veya tampon alanın oluşturulmasıdır (Küpcü, 2005). Tampon alan 
oluşturma genellikle çeşitli özelliklerin etki alanlarının belirlenmesi kullanılmaktadır. Tampon belirli bir yarı çap dahilinde uzanan tek bir halka veya farklı uzaklıktaki mesafe aralıklarını içeren ve art arda sıralanan birden fazla halkalar şeklinde olabilmektedir. Tampon alanlarını belirlemek, bu alanlarda planlanan hizmetlerde yanlış kullanımları belirlemek, yeni yapılacak bir uygulama için yer seçiminde karar verme mekanizmalarını oluşturmak ve yol göstermek gibi amaçlar için kullanılabilmektedir (Küpcü, 2005).

Analiz bir işlev ya da amaç için yapıldığında, ortaya çıkan tampon bölge için "hizmet alanı" olarak ifade edilmektedir. Bu nedenle araştırmada itfaiye istasyonları için oluşturulan tampon bölgeler, bu istasyonların hizmet alanlarını göstermektedir. Hizmet alanlarını belirlemek için öncelikle bu istasyonlara ait noktasal verileri baz alınarak, bir yarıçap mesafesinin belirlenmesi gerekmektedir. Erzincan merkezi dikkate alınarak, gün içinde farklı saatlerdeki değişken trafik yoğunlukları, sürücülerin itfaiye araçlarına yol verme konusundaki tutumları, trafik ışıkları, yol yapılarının asfalt ya da stabilize olma durumu, yol genişliklerinin yetersizliği veya yolların anayoltali yol olması gibi faktörler göz önüne alındığında azami hız, itfaiye araçları için $45 \mathrm{~km} / \mathrm{s}$ olarak belirlenmiştir. Müdahale süresi iki farklı şekilde ele alınmıştır. Nişancı vd. (2012), 110 itfaiye istasyonlarının konumları hakkında yaptığı çalışmada itfaiye araçlarının hızlarını saatte ortalama $45 \mathrm{~km}$ olarak kullanmış $3 \mathrm{dk}$., $5 \mathrm{dk}$. ve $7 \mathrm{dk}$. süreler için hesapladıkları ulaşım alanlarıyla analizler yapmıştır (Nişancı, vd., 2012). Yapılan bu çalışmalar dikkate alındığında ilk müdahale süresi $5 \mathrm{dk}$. olarak belirlenmiştir. İkinci müdahale süresi için ise yangın müdahalelerinde ideal sürenin 10 dakikanın altında olması gerekliliği dikkate alınmıştır. Bu sürelerin ortalama 2 dakikasının çağrının cevaplanması, ekibin hazırlanma ve yola çıkış süresi olarak hesaplanmıştır. Böylece 110 yangın çağrıları için $5 \mathrm{dk}$. ve $10 \mathrm{dk}$ 'lı hizmet alanları için, $3 \mathrm{dk}$. ve $8 \mathrm{dk}$. olacak şekilde ulaşım süreleri hesaplanarak buffer (tampon) analizleri yapılmıştır. Bu süreler dikkate alınarak itfaiye araçları için yarı çaplar ((r1: saatteki ortalama hızı $45 \mathrm{~km}$ olan bir aracın $3 \mathrm{dk}$. 'da gideceği mesafe), (r2: saatteki ortalama hızı $45 \mathrm{~km}$ olan bir aracın $8 \mathrm{dk}$.'da gideceği mesafe)) doğru orantıyla hesaplanmıştır. Sonuçta analizler için r1:2,25 km ve r2:6 km olarak belirlenmiştir.

Analizde kullanılan tampon bölgelerin, çalışma alanı genelindeki öz nitelik verilerinden ne kadarını kapsadığını bulabilmek için ArcGIS programında yer alan ArcToolbox içindeki "intersect" analizi kullanılarak yapılmaktadır. Örneğin; çalışma yapılan ildeki bir istasyona ait hizmet alanının (buffer alanının), gelen toplam çağrıların ne kadarını kapsadığını bulabilmek için kullanılır.

\subsubsection{Zaman Serileri}

Zaman serisi, ölçümlerden elde edilen serinin zaman içindeki hareketini gözlemler. (Bozkurt, 2007). Analizde zaman serilerinin kullanılmasının amacı, bu serideki değişkenlerin gelecekteki değerlerinin tahmin (forecast) edilmesidir. Zaman serisi analizleri, SPSS paket programı kullanılarak yapılmıştır. Zaman serisi analizlerinin yapılması için çeşitli varsayımlar bulunmaktadır. Verilerin normal dağılım gösteriyor olması ve serinin durağan olması en önemli varsayımlardandır. Serinin durağan olması yani eğilimden arındırılması gerekmektedir. Bir serinin durağan olmasını sağlamak sahte regresyonu önlemektedir. Böylece durağan bir seri ile gelecek tahmini yapmak elde edilen modellerin istatistiksel olarak anlamlı olmasını sağlamaktadır (Bayata, 2010). Zaman serisi analizinde otokorelasyon ve kısmi otokorelasyon fonksiyonları önemli iki fonksiyondur. Bu çalışmada Erzincan Belediyesi İtfaiye Müdürlügü’nden alınan 110 acil çağrılarının talebini tahmin etmek için Box-Jenkins yöntemi (ARIMA modeli) kullanılmıştır.

Otoregresif bütünleşik hareketli ortalama (ARIMA(p,d,q)) süreci, Box-Jenkins yöntemi olup, zaman serisinin tahmin edilecek olan dönemi, bu serinin geçmiş dönemdeki değerlerinin ağırlık toplamı ile hata teriminin doğrusal bir bileşimi ile açılanmaktadır. Söz konusu yöntemin varsayımlarından biri serinin durağan olmasıdır. Fakat birçok serinin ortalama ve varyansında 
Erzincan İli 110 Acil Çağrılarının Coğrafi Bilgi Sistemleri ve Farklı İstatistiksel Analiz Yöntemleri ile Değerlendirilmesi

zamana bağlı olarak değişim olmakta ve seri durağan dışı hareket etmektedir. Bu nedenle söz konusu serinin farkı alınarak durağan hale getirilmeye çalışılır. Durağan olmayıp belirli sayıda farkı alınarak durağan hale getirilen serilere uygulanan AR ve MA modellerinin birleşimi ARIMA modellerini oluşturmaktadır. AR (p), MA(q) ve serinin fark alma derecesi d olan model, (p, d, q) dereceden "otoregresif bütünleşik hareketli ortalama modeli" olarak adlandırılır ve ARIMA $(p, d$, q) ile gösterilir (Solak, 2013).

Durağan olmayan seriler ile çalışıldığından d fark alma derecesi olarak kullanılmaktadır. Serinin birinci farkı alınıp durağan hale geliyorsa d'nin derecesi 1, durağan hale gelmiyorsa ikinci farkı alınıp d'nin derecesi 2 olarak belirlenir. Böylece seri d dereceden durağan hale geliyorsa I(d) olur (Tarı, 2008). d kadar fark alınıp durağan hale gelen seri, d. dereceden fark serisi olarak adlandırılır. AR ve MA süreçlerinde ACF ve PACF korelogramlarına bakılarak model derecesi belirlenebilir.

\subsubsection{Yapay Sinir Ağları}

Yapay sinir ağları (YSA), doğrusal ilişki olmayan değişkenlerin modellenmesinde kullanılmakta ve iyi sonuçlar vermektedir (Bayata, 2010). YSA uygulaması için MATLAB 2008 yazılımı kullanılarak bir program kodu yazılmıștır. Bu program kodu transfer fonksiyonları (tansig-purelin-logsig), eğitim fonksiyonları (trainbr-trainlm) ve gizli tabakadaki nöron sayısı $(1,2,3,4 \ldots . . n)$ arasında döngü yapabilen bir yazılım olarak geliștirilmiștir. Yazılımın diğer özelliği ise ağın performans belirleme kıstası olarak ortalama karesel hatayı (OKH) alması, iterasyon sayısını isteğe bağlı olarak değiștirebilmesi ve ağın eğitiminin istenilen hassasiyette sonlandırabilmesidir (Bayata ve Hattatoğlu, 2011).

\section{BULGULAR VE TARTIŞMA}

Erzincan mahalleleri 110 itfaiye istasyonuna gelen çağrıların nüfus, toplam çağrı sayısı, 100 kişi başına düşen çağrı sayısı, yüzölçümü, 1 ha düşen kişi ve çağrı sayıları Tablo 1'de gösterilmiştir.

Tablo 1. Erzincan mahallelerinden yapılan yangın çağrılarının nüfus ve yüzölçümüne göre dağılımları

\begin{tabular}{lccclccc}
\hline \multicolumn{1}{c}{ Mahalle } & $\begin{array}{c}\text { Toplam } \\
\text { Yangin } \\
\text { Çağrısı }\end{array}$ & Nüfus & $\begin{array}{c}\text { Yüz } \\
\text { Ölçüm } \\
\text { (Ha) }\end{array}$ & Mahalle & $\begin{array}{c}\text { Toplam } \\
\text { Yangın } \\
\text { Çağrısı }\end{array}$ & $\begin{array}{c}\text { Yüz } \\
\text { Nüfus }\end{array}$ & $\begin{array}{c}\text { Ölçüm } \\
\text { (Ha) }\end{array}$ \\
\hline Akşemsettin & 2 & 2.382 & 38 & İnönü & 32 & 5.127 & 71 \\
Akyazı & 9 & 2.917 & 2.599 & İstasyon & 2 & 0 & 444 \\
Arslanlı & 1 & 5.496 & 88 & İzzetpaşa & 53 & 2.642 & 376 \\
Atatürk & 15 & 4.498 & 74 & Karaağaç & 34 & 409 & 43 \\
Bahçelievler & 4 & 3.560 & 58 & Kavakyolu & 3 & 6.459 & 1.174 \\
Barbaros & 3 & 1.954 & 33 & KazımKarabekir & 5 & 3.744 & 74 \\
Başbağlar & 6 & 4.645 & 126 & Kizılay & 11 & 1.311 & 26 \\
Beybağl & 0 & 0 & 886 & Kurutilek & 6 & 552 & 657 \\
Cumhuriyet & 5 & 7.057 & 102 & Mengüceli & 11 & 3.735 & 221 \\
Çarşı & 3 & 2.684 & 37 & Mimar Sinan & 19 & 10.286 & 604 \\
Çukurkuyu & 5 & 5.322 & 1.246 & Taksim & 7 & 1.580 & 50 \\
Demirkent & 12 & 11.409 & 329 & Ulalar & 12 & 5.447 & 906 \\
Ergenekon & 6 & 6.885 & 74 & Yalnızbağ & 2 & 3.295 & 9.099 \\
Ersevenler & 6 & 1.054 & 19 & Yavuz Selim & 2 & 7.813 & 72 \\
Fatih & 10 & 3.797 & 81 & Yaylabaşı & 40 & 1.572 & 3.847 \\
Geçit & 5 & 5.510 & 1.672 & Yenimahalle & 1 & 2.496 & 26 \\
Gülabibey & 18 & 1.436 & 84 & Yoğurtlu & 7 & 4.414 & 1.307 \\
Halitpaşa & 3 & 2.702 & 56 & Yunus Emre & 8 & 5.431 & 58 \\
Hocabey & 4 & 1.562 & 30 & & & & \\
\hline
\end{tabular}


Toplam çağrı sayıları incelendiğinde, daha büyük yüz ölçümüne sahip mahalleler olmasına karşın 53 adet yangın olayıyla en çok çağrının İzzetpaşa Mahallesi'nden geldiği ve nüfusunun ortalamalarda olduğu görülmemektedir. Yalnızbağ en büyük yüz ölçümüne sahip olmasına karşın 1 hektar başına düşen çağrı sayılarının oranı incelendiğinde en sonda yer aldığı, Karaağaç mahallesinin ise yüz ölçümüne göre en fazla çağrı yoğunluğuna sahip olduğu görülmektedir.

Erzincan 110 İtfaiye müdürlüğünden alınan bilgiler, literatürde yapılan çalışmalar ve yangın yönetmeliği dikkate alındığında 110 itfaiye istasyonunun hizmet alanı için ortalama $45 \mathrm{~km} / \mathrm{sa}$ hızla ulaşılabilecek $5 \mathrm{dk}$. ve $10 \mathrm{dk}$.'llk buffer alanları incelenmektedir. Erzincan belediyesi itfaiye istasyonuna gelen toplam yangın çağrılarının mahallelere dağılımıyla beraber, $5 \mathrm{dk}$.'lık ve 10 dk.'lık hizmet alanlarını gösteren harita Şekil 2'de verilmiştir.

Erzincan belediyesi 110 itfaiye istasyonunun hesaplanan yarıçaplardaki hizmet alanları, buffer analizi kullanılarak değerlendirilip, 5 dk.'lık hizmet alanı incelendiğinde en fazla yangın çağrısının geldiği İzzetpaşa mahallesinin neredeyse tamamını, merkez mahallelerin büyük bölümünü ile bağlanan Yoğurtlu ve Geçit’in bir kısmını kapsıyor olduğu görülmektedir. Buna karşın şehrin batı mahallelerinin, merkeze bağlanan Ulalar, Kavakyolu, Çukurkuyu, Yalnızbağ, Demirkent, Akyazı ve Yaylabaşı'nın tamamen hizmet alanı dışında kaldığı tespit edilmiştir. Bu bölgelerin dışında cezaevi, Erzincan-Erzurum, Erzincan-Sivas ve Erzincan-Gümüşhane karayollarının da tamamının istasyon hizmet alanları dışında kaldığı görülmüștür.

Mevcut mahalle haritası üzerinde $10 \mathrm{dk}$. 'lk hizmet alanı için buffer alanı yerleştirildiğinde Beybağı'nın bir kısmı hariç bütün merkez mahalleleri, Yoğurtlu ve Demirkent'in tamamını, Kavakyolu, Ulalar, Geçit, Akyazı ve Yaylabaşı'nın bir kısmını kapsadığı görülmektedir. Çukurkuyu ve Yalnızbağ'ın tamamının, Yaylabaşı'nın ağırlıklı olarak güney bölümde kalan yerleşim bölgeleri olmak üzere büyük kısmının hizmet alanı dışında kaldığı görülmektedir. Ayrıca cezaevi, ErzincanErzurum, Erzincan-Sivas ve Erzincan-Gümüşhane karayollarının da tamamen hizmet alanları dışında kaldığı görülmüştür.

110 itfaiye istasyonlarına ait 5 dk.'llk hizmet alanının, toplam çağrıların mahallelere göre dağılımıyla incelendiğinde yaklaşık \%39 'unu kapsadığı hesaplanmıştır. Bu oran 10 dk.'llk hizmet alanında incelendiğinde ise \%82' ye yükselmektedir. Erzincan merkez 110 itfaiye istasyonunun toplam çağrıları için $5 \mathrm{dk}$. ve $10 \mathrm{dk}$.'lık hizmet alanını gösteren harita Şekil 2'de verilmiştir.

Ayrıca 110 acil çağrılarına ait zaman serileri ve yapay sinir ağları incelenmiștir. İtfaiye çağrılarına ait SPSS paket programı kullanılarak elde edilen zaman serisi grafiği ise Şekil 3'de verilmiştir.

Zaman serisi grafiği incelendiğinde 29. ve 41. haftalarda itfaiye çağrılarının maksimum seviyeye ulaştığı görülmektedir. Bu durumda bazı haftalarda yangın çağrılarında yoğunluk olduğu söylenebilir. Buradan mevsimsel dalgalanma olabileceği görülmektedir. Buradaki dalgalanmayı daha net anlayabilmek ve durağanlığın tespiti için otokorelasyon (ACF) ve kısmi otokorelasyon (PACF) grafiklerine bakılmıştır (Şekil 4, 5, 6 ve 7).

İtfaiye çağrılarına ait ACF korelogramına bakıldığında ilk iki gecikmenin, PACF korelogramına bakıldığında ise ilk üç gecikmenin güven aralığının dışında kaldığı görülmüş ve verilerin durağan olmadığı tespit edilmiştir. Bu nedenle fark serisi alınarak verilerin mevsimsellikten ayrıştırılması ve durağan bir hale getirilmesi gerekmektedir. Birinci fark serisi alınıp serinin durağan olmadığı belirlenmiştir. İkinci fark serisi alındığında ise aşağıdaki korelogramlarda görüldüğü gibi gecikmelerin büyük çoğunluğunun güven aralığı içerisinde olduğu belirlenmiştir. 
Erzincan İli 110 Acil Çağrılarının Coğrafi Bilgi Sistemleri ve Farklı İstatistiksel Analiz Yöntemleri ile Değerlendirilmesi

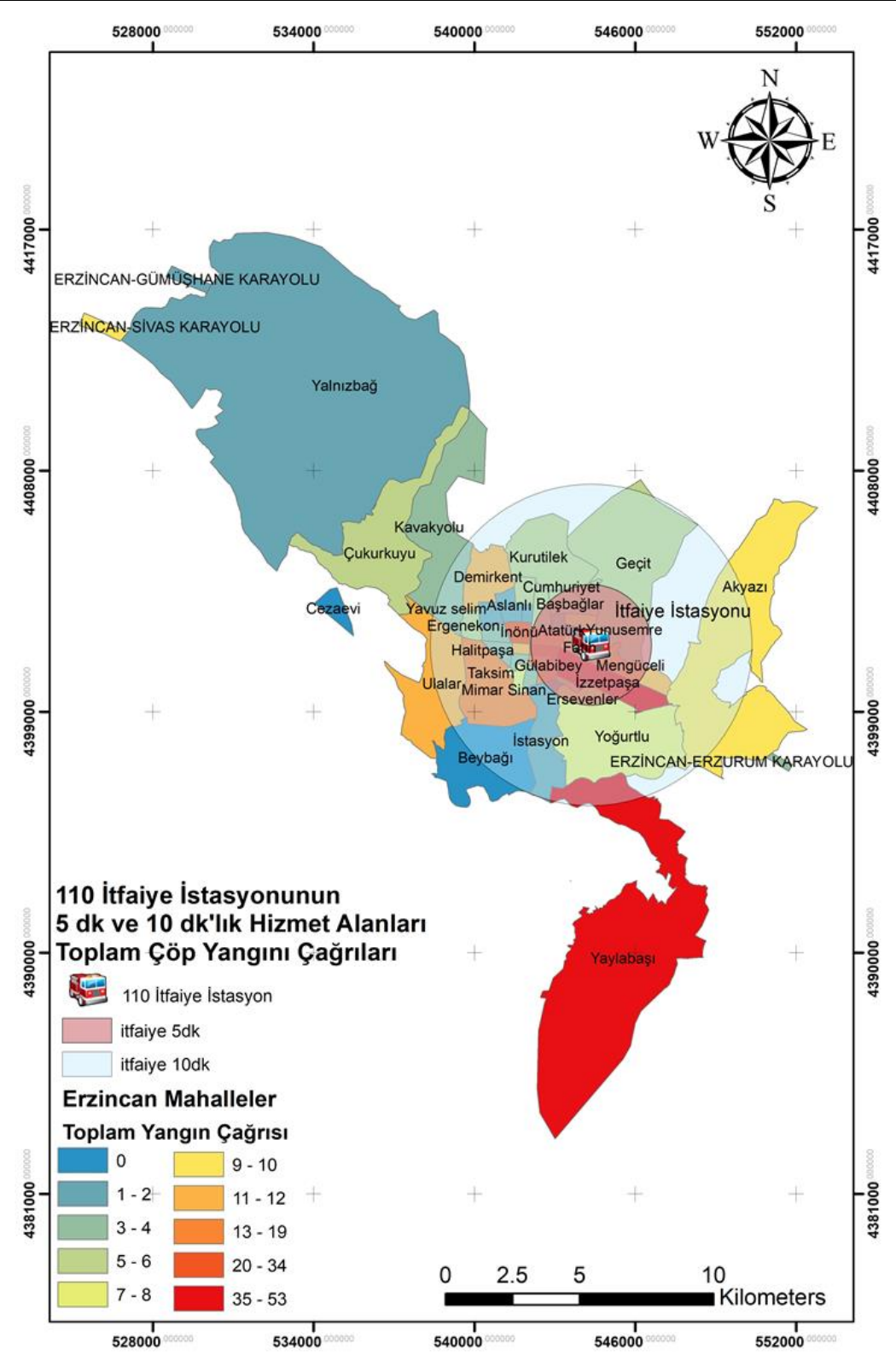

Şekil 2. Erzincan merkez 110 itfaiye istasyonunun toplam çağrıları için $5 \mathrm{dk}$. ve $10 \mathrm{dk}$.'lık hizmet alanı

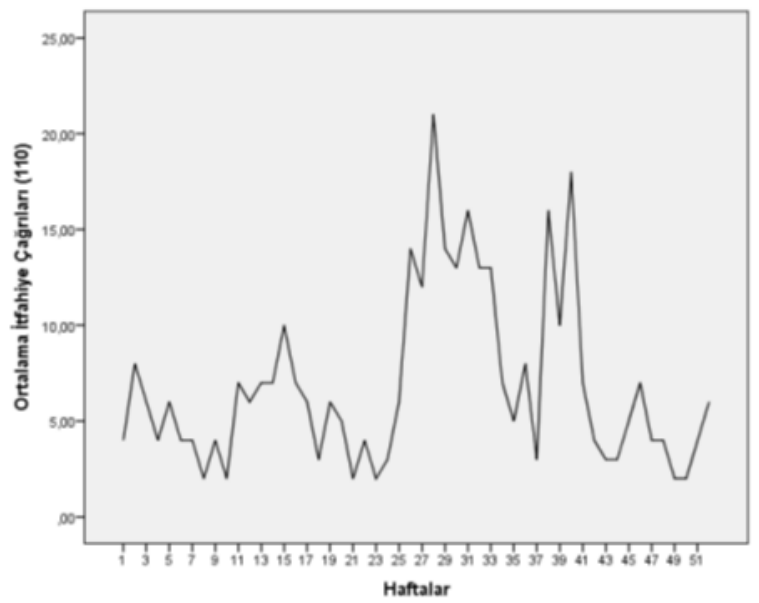

Şekil 3. İtfaiye çağrılarının zaman serisi grafiği 


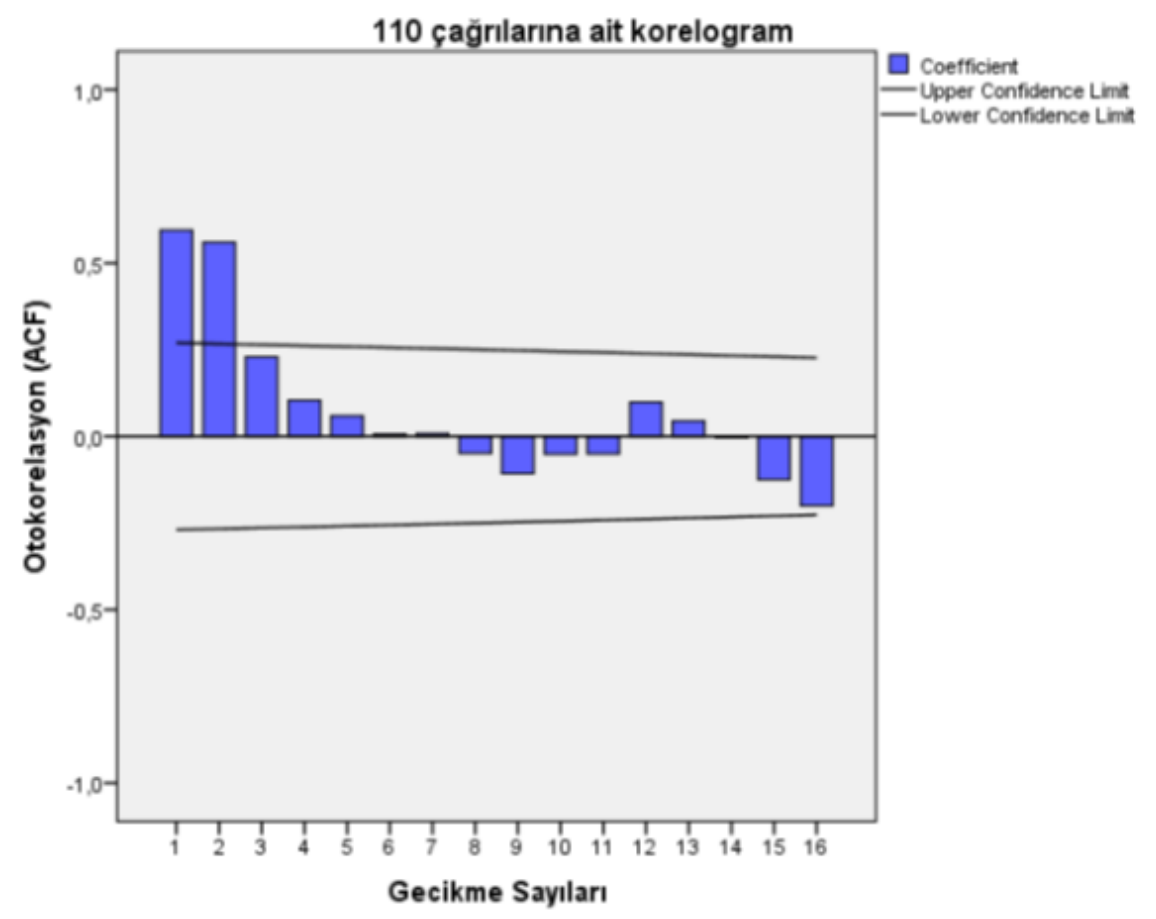

Şekil 4. İtfaiye çağrılarının otokorelasyon grafiği

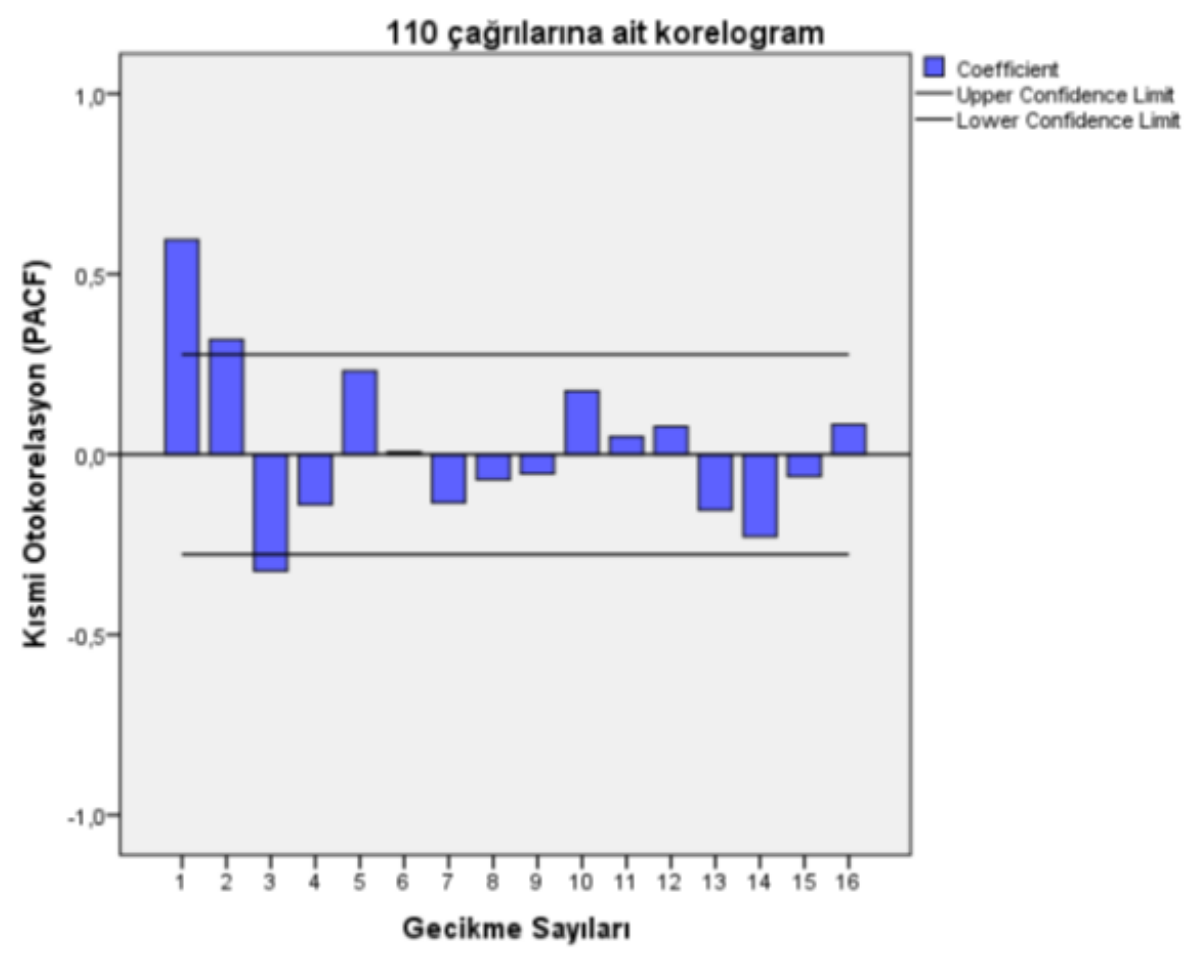

Şekil 5. İtfaiye çağrılarının kısmi otokorelasyon grafiği 
Erzincan İli 110 Acil Çağrılarının Coğrafi Bilgi Sistemleri ve Farklı İstatistiksel Analiz Yöntemleri ile Değerlendirilmesi

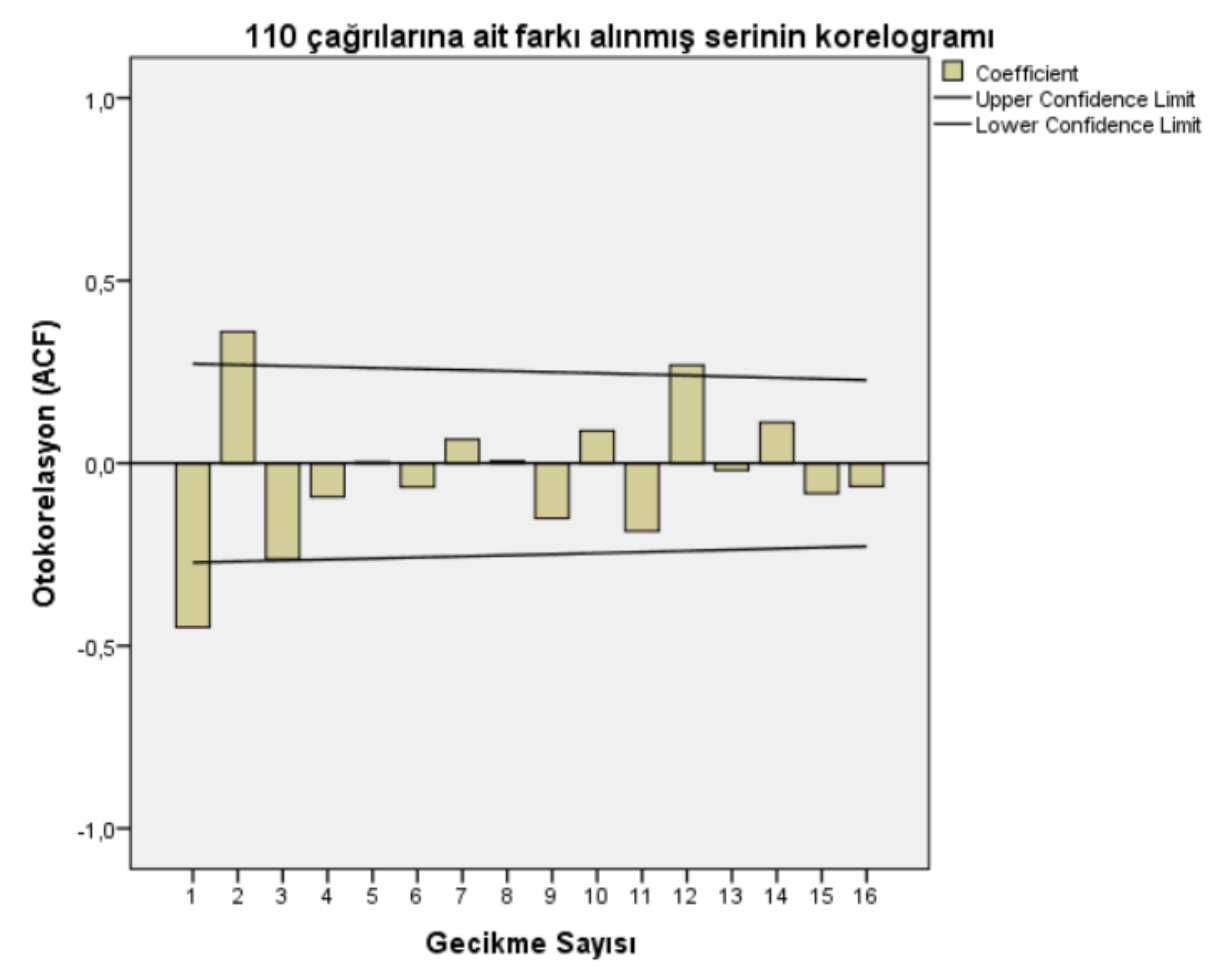

Şekil 6. İtfaiye çağrılarına ait farkı alınmış serinin otokorelasyon grafiği

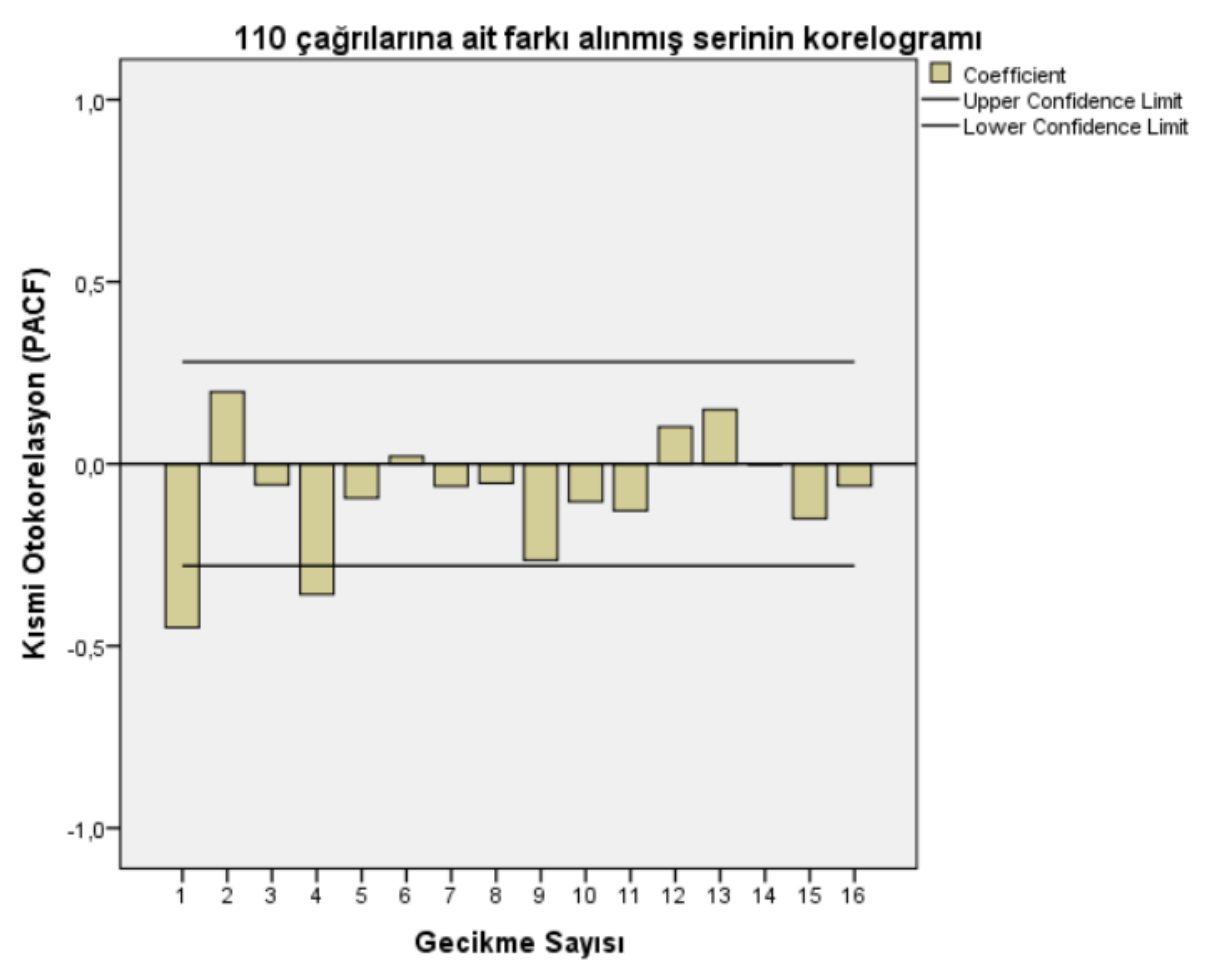

Şekil 7. İtfaiye çağrılarına ait farkı alınmış serinin kısmi otokorelasyon grafiği

Otokorelasyon ve kısmi otokorelasyon grafikleri incelendiğinde serinin durağan olduğu söylenebilir. Seriye uygun model belirleme işlemi de farkı alınmıș serinin ACF ve PACF grafiklerine göre yapılmıştır. Bu grafiklere ait en uygun model ise ARIMA $(1,2,1)$ olmaktadır. $\mathrm{Bu}$ durumda ARIMA modeline ait $d=2$ olarak belirlenmiştir. AR ve MA modellerinin parametre değerlerinin tahmini için yapılan analiz sonuçları ise Tablo 2'de verilmiştir. 
Tablo 2. ARIMA $(1,2,1)$ modeli parametre tahmini analiz sonuçları

\begin{tabular}{lcccc}
\hline Parametre & Katsay1 & Standart Hata & t-istatistiği & Olas1lık değeri \\
\hline Sabit &,- 009 &, 026 &,- 337 &, 737 \\
Fark & 2 & & & \\
AR (1) &,- 427 &, 135 & $-3,155$ &, 003 \\
MA (1) &, 996 & 1,273 &, 782 &, 438 \\
\hline
\end{tabular}

Tablo 2'de görüldüğü üzere ARIMA (1,2,1) modelinin parametre tahminlerine göre AR(1) modeli anlamlı $(p<0,01)$ iken MA (1) modeli anlamlı değildir $(p>0,05)$. Genel olarak parametre tahminlerinin anlamlı olan, otokorelasyon sorunu olmayan en uygun modelin ARIMA $(1,2,1)$ olduğuna karar verilmiştir.

Şekil 8'de görüldügü üzere verilere uygun modelin Yt = Yt-1 +0,67et-1 + et olduğu tespit edilmiștir. Tahmin edilen modelin açıklayıcılığının ise R2 $=0.41$ olduğu görülmüştür. Hata terimlerine ait korelogramlar ise Şekil 9 'da verilmiştir.

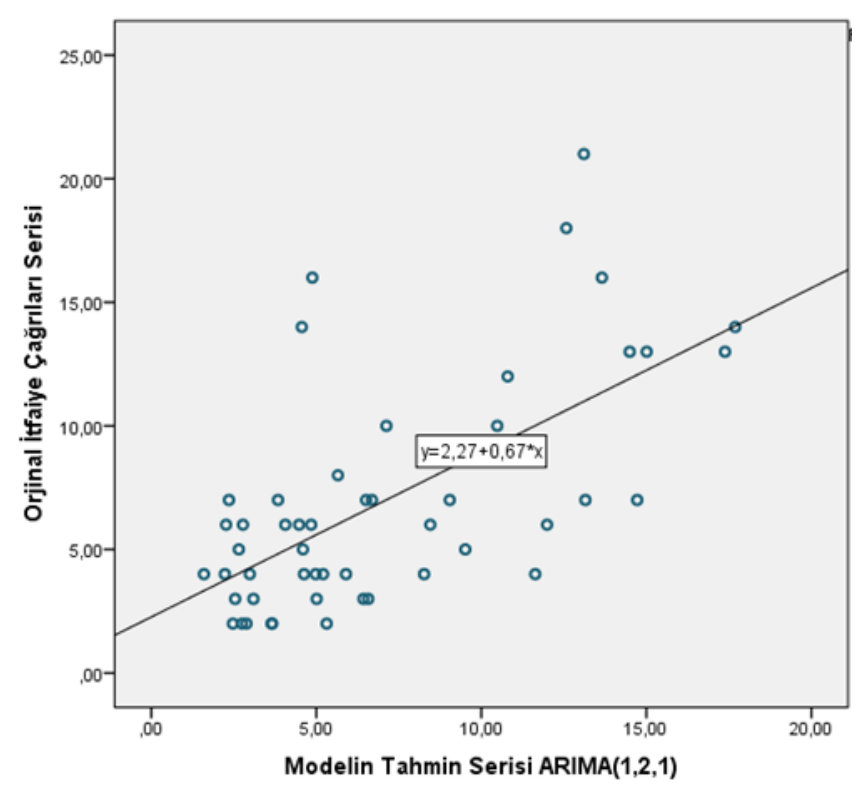

Şekil 8. ARIMA $(1,2,1)$ modelinin tahmin serisi

Şekil 9'da görüldüğü gibi hata terimlerine ait otokorelasyon değerlerinin tamamının güven aralığı içinde yer aldığı ve serinin durağan olduğu söylenebilir. Bu nedenle akgürültü (white noise) serisi olduğu ve model için uygun bir seri elde edildiği tespit edilmiştir. Modelin uygunluğunun tespit edilmesi için hata terimlerinin otokorelasyon değerlerinden faydalanılarak Box-Ljung testi de yapılmış ve Tablo 3'de sunulmuştur.

Tablo 3'e göre yapılan analizde hata terimlerinin bağımsız olduğu sıfır hipotezi kabul edilmiş ve modelin uygun olduğu sonucuna ulaşılmıştır ( $p>0,05 ; \mathrm{Q} 16=22,077)$. Tespit edilen modelin açıklayıcllığının ise $\mathrm{R} 2=0,30$ olduğu görülmüştür. Tahmin edilen ve gözlemlenen serinin uyum grafiği ise Şekil 10'da sunulmuştur. 
Erzincan İli 110 Acil Çağrılarının Coğrafi Bilgi Sistemleri ve Farklı İstatistiksel Analiz Yöntemleri ile Değerlendirilmesi

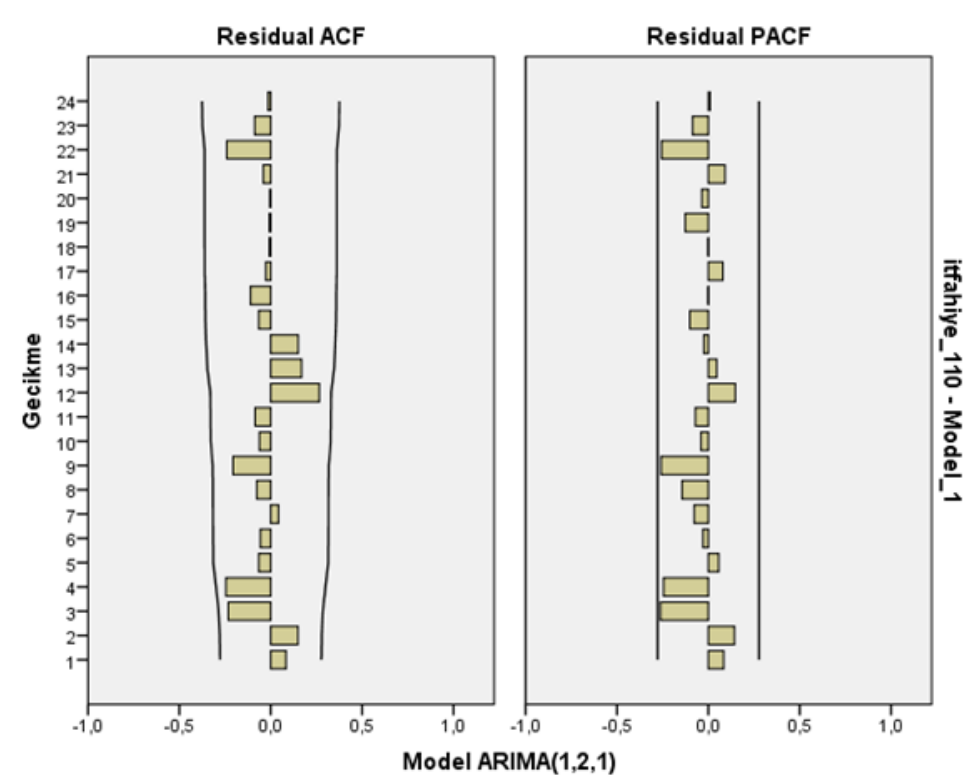

Şekil 9. ARIMA $(1,2,1)$ modelinin hata terimlerine (Residual) ait otokorelasyon ve kısmi otokorelasyon değerleri

Tablo 3. ARIMA $(1,2,1)$ Modeli İçin İstatiksel Uygunluk Tablosu

\begin{tabular}{lcccccc}
\hline \multicolumn{2}{l}{ Model istatistiği } & \multicolumn{1}{l}{} & & & \\
\hline & $\begin{array}{c}\text { Tahminci } \\
\text { Sayısı }\end{array}$ & $\begin{array}{c}\text { Model Uygunluk } \\
\text { İstatistiği }\end{array}$ & \multicolumn{2}{c}{ Ljung-Kutusu $Q_{(18)}$} & & $\begin{array}{c}\text { Aykırı } \\
\text { Değerlerin } \\
\text { Sayısı }\end{array}$ \\
\cline { 2 - 7 } Model & & $\mathrm{R}^{2}$ & İstatistik & Sd & $\mathrm{p}$ & \\
\hline $\begin{array}{l}\text { Acil 110- } \\
\text { Model-1 }\end{array}$ & 0 &, 303 & 22,077 & 16 & 0,141 & 0 \\
\hline
\end{tabular}

\section{Ittfaiye Verileri Tahmin Grafiğ}

25

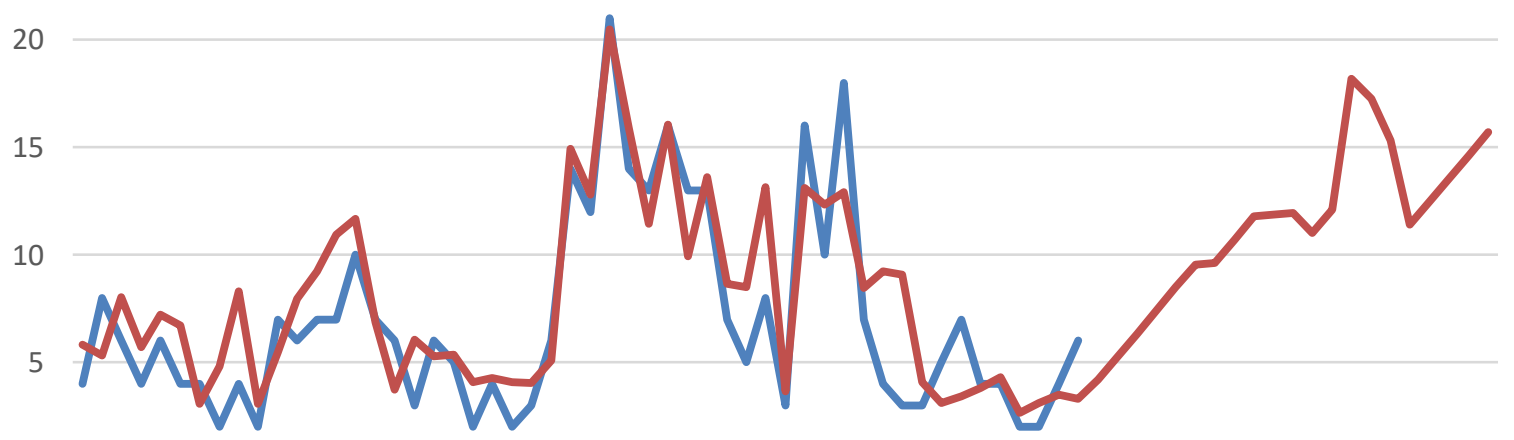

0

1355791113151719212325272931333537394143454749515355575961636567697173 Seri2

Şekil 10. İtfaiye verilerine ait gözlemlenen-tahmin serisi uyum grafiği ve gelecek tahmini 
Şekil 10'da verilen tahmin grafiğine göre seri 1 gözlemlenen veri grafiğini, seri 2 ise elde edilen modelin tahmin grafiğini göstermektedir. Seri 2 grafiğine göre itfaiye çağrılarının gelecek haftalarda artış göstereceği ön görülmektedir.

Model ARIMA(1,2,1) modelin değerlendirilmiş olup Yapay Sinir ağları ile de aynı model çalışılmış ve iki farklı yöntem karşılaştırılmıştır. YSA nın ZSA istatistiksel olarak daha anlanmalı olduğu görülmüștür. YSA yönteminde model incelendiğinde eğitim setinde R2=0,53 olduğu modelin tamında ise $\mathrm{R} 2=0,51$ olduğu bulunmuștur. Bu durumda YSA yönteminin ZSA klasik yönteme göre daha başarılı olduğu anlașılmıştır (Şekil 11).

Şekil 12‘de YSA Regresyon performans grafiğine bakıldığında, Response Plot grafiğinde yatay eksende Time değişkeni, dikeyde de Target değişkenini göstermektedir. YSA sonuçların incelendiğinde zaman hesaplanan sistemin cevaplarıyla eş zamanlıdır, hata grafiğini gösteren alt grafiğe bakarak yorumlanabilir. Çıktı hata ve zaman grafiği ve tahmin serisinin grafiğinde 27-30. Haftalardaki pik dikkat çekmektedir.

Şekil 13'deki Training State etiğim istatistiklerine bakıldığında Gradient logaritmik ölçekte her iterasyon için bir geri yayılım değeridir. 19862 değeri hedef fonksiyonun yerel minimum alt noktasına ulaştığı görülmüştür.

Şekil 14 incelendiğinde En Küçük Kareler model hatalarının otokorelasyon ve kısmi otokorelasyon katsayılarının grafiklerinde modele ait hataların otokorelasyon ve kısmi otokorelasyon katsayıları serilerin durağan olmadığını ve kısmi otokorelasyon katsayılarından ilkinin anlamlı olması AR(1) modelinin geçerli olduğunu göstermektedir.

Şekil $15^{\prime}$ de devir performansı grafiği gösterilmektedir. H.K.O. ve iterasyon sayıları verilmiş olan bu grafikte performans ölçütü olarak H.K.O. kullanılmıștır. Model; 0,0002'lik değerle en küçük H.K.O. ya sahiptir.
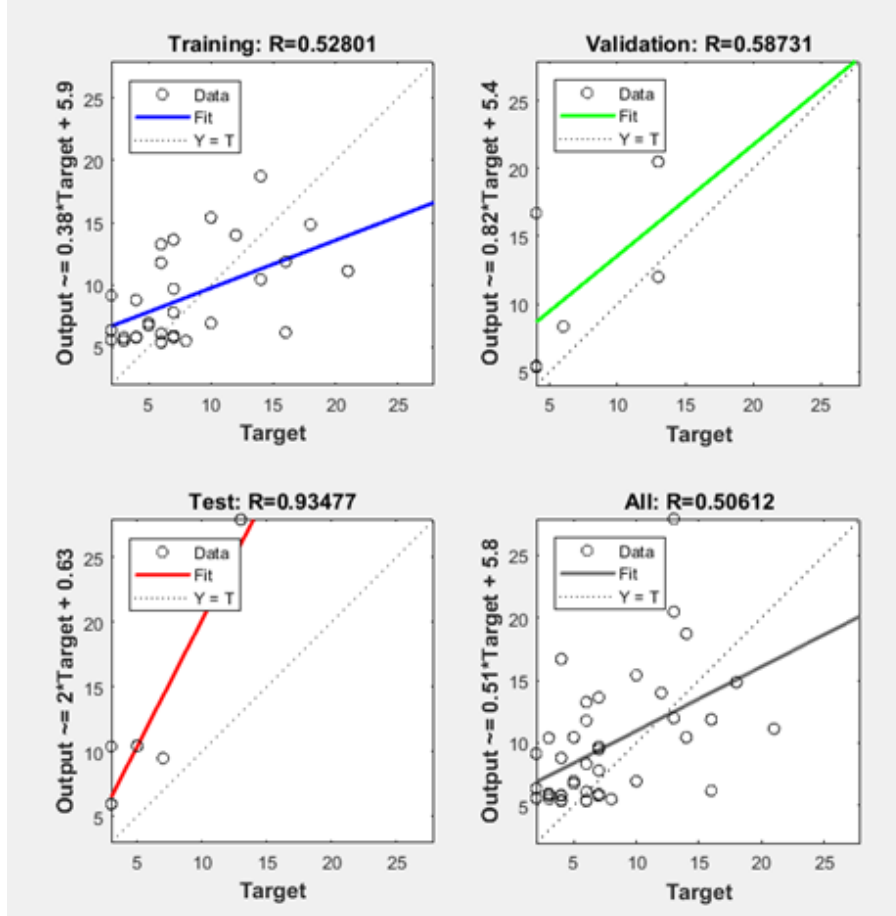

Şekil 11. İtfaiye verilerine ait yapay sinir ağları modeli 
Erzincan İli 110 Acil Çağrılarının Coğrafi Bilgi Sistemleri ve Farklı İstatistiksel Analiz Yöntemleri ile Değerlendirilmesi

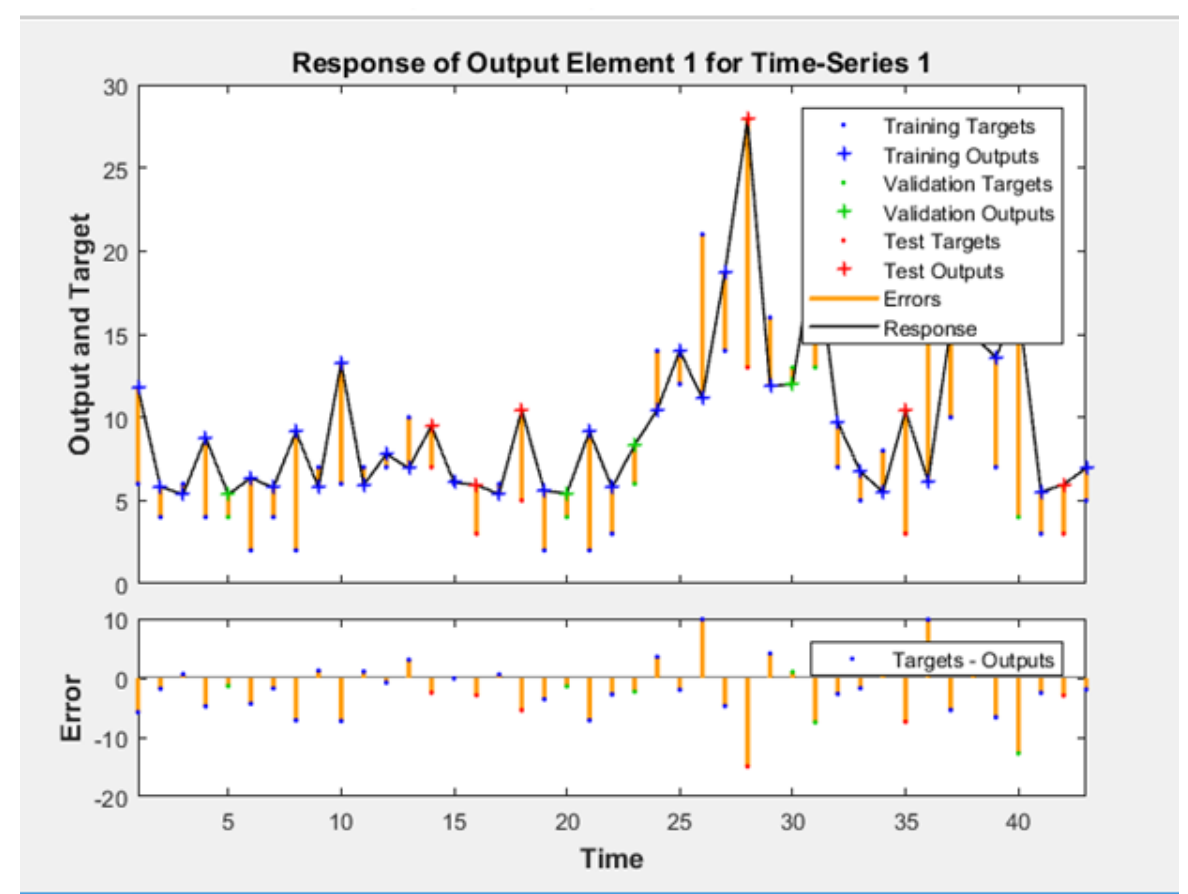

Şekil 12. İtfaiye verilerine ait YSA Regresyon performans grafiği

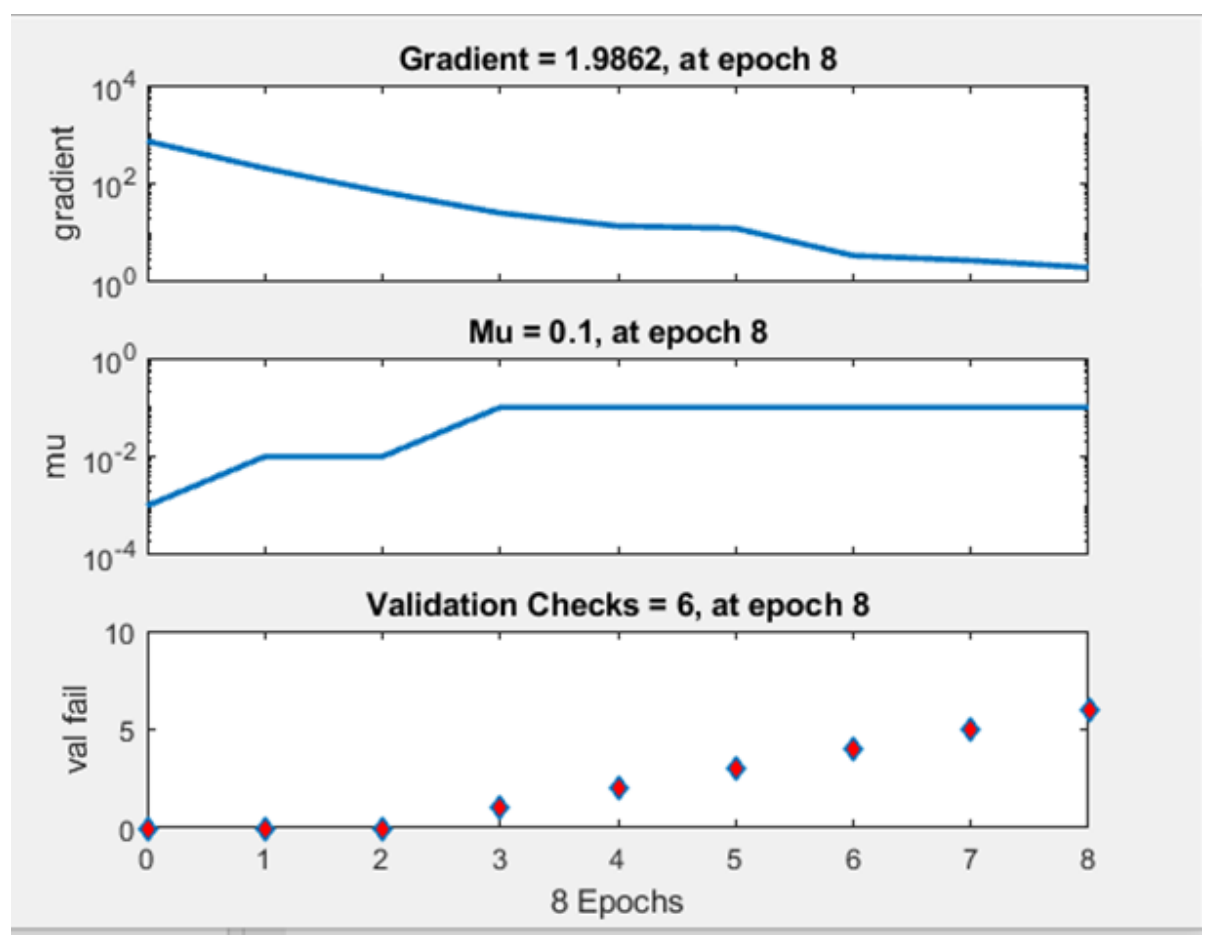

Şekil 13. İtfaiye verilerine ait training state eğitim istatistikleri 


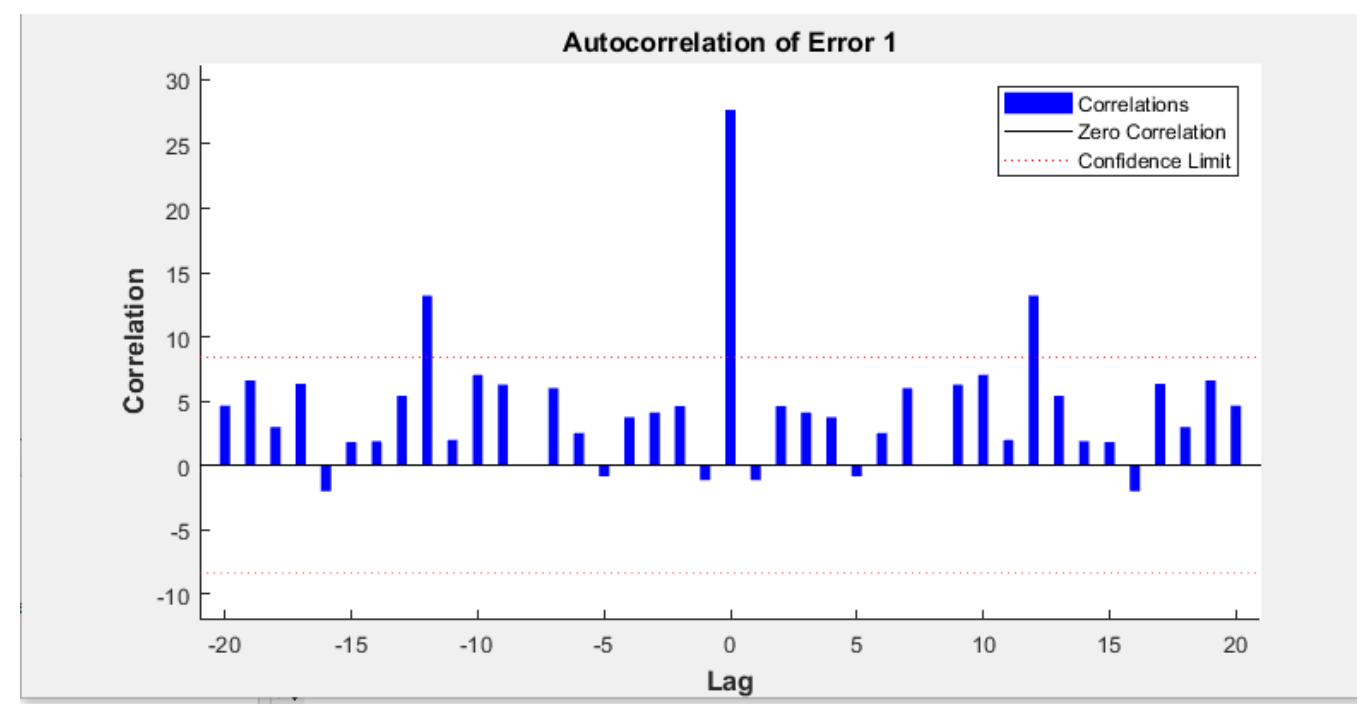

Şekil 14. İtfaiye verilerine ait en küçük kareler model hataları

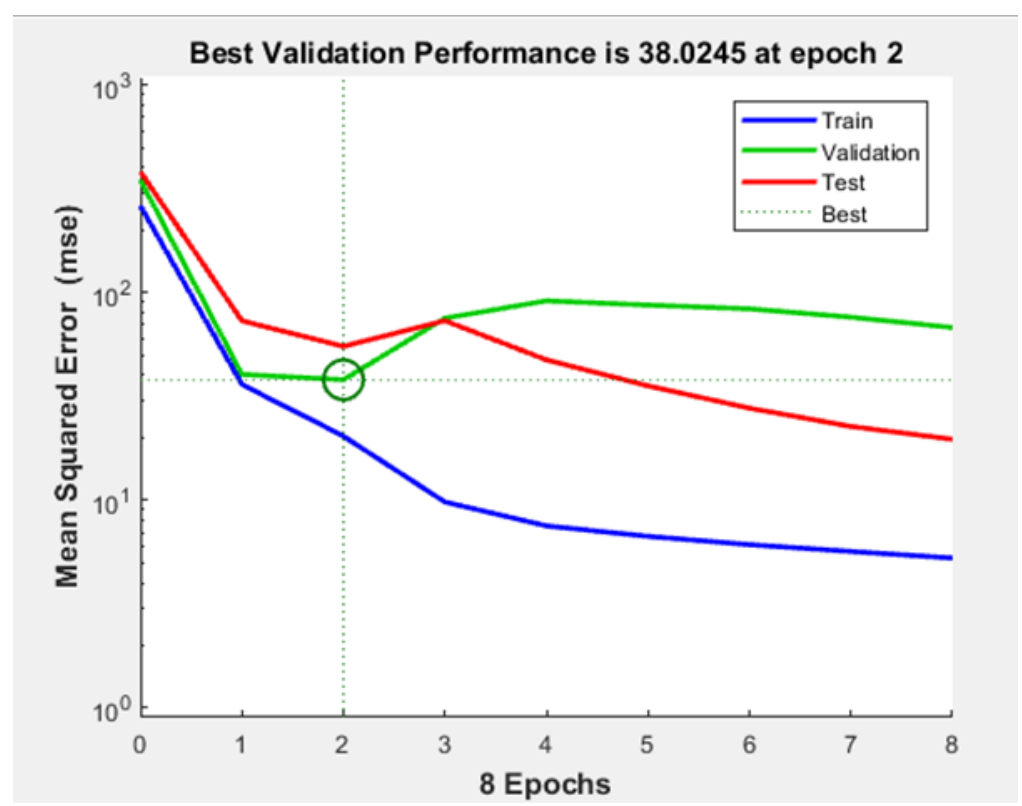

Şekil 15. İtfaiye verilerine ait devir performansı grafiği

Ağ performansı incelendiğinde hata histogramında mavi kısımlar eğitim serisini, yeșil alanlar geçerliliği, kırmızı kısımlar da tahmin sersini ifade etmektedir (Şekil 16) . Histogram incelendiğinde uyumsuz değerler hakkında fikir verebilir. Grafik incelendiğinde hataların çoğunun -9,371 ile 9,164 aralığına düştüğünü görebiliriz. Uyumsuz değerlerin varlı̆̆ı regresyon grafiğinden daha rahat incelenebilir. 
Erzincan İli 110 Acil Çağrılarının Coğrafi Bilgi Sistemleri ve Farklı İstatistiksel Analiz Yöntemleri ile Değerlendirilmesi

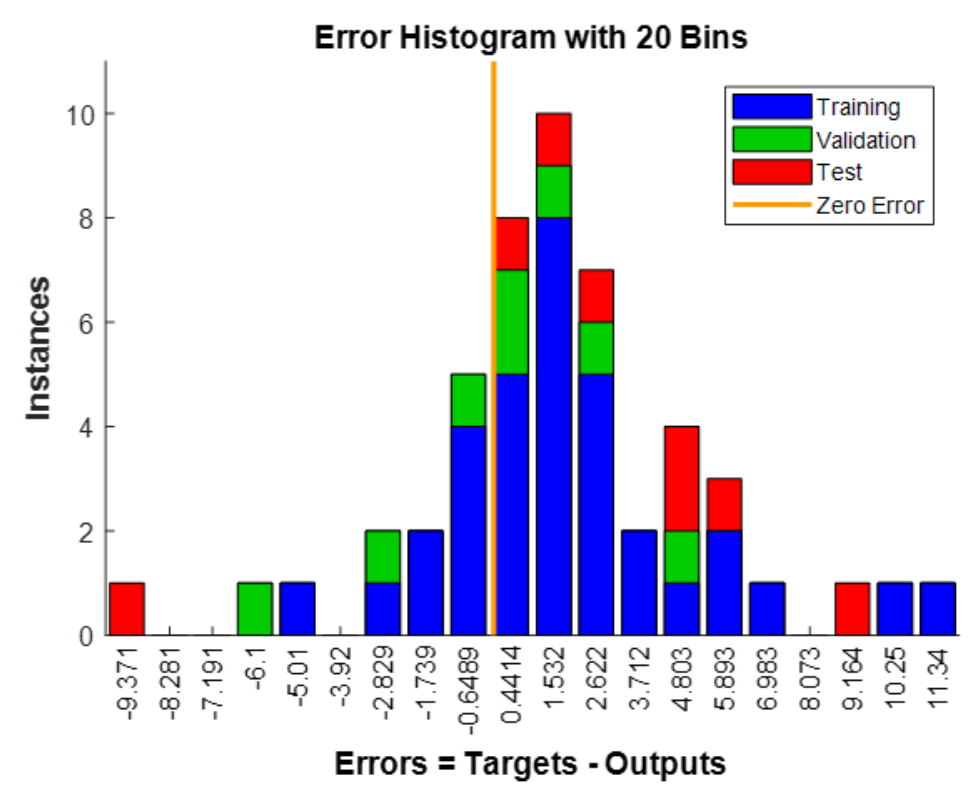

Şekil 16. İtfaiye verilerine ait ağ performansı

\section{SONUÇLAR}

Bütün acil çağrılarda olduğu gibi yangın çağrılarında da olabildiğince erken ve hızlı bir şekilde yapılacak ilk müdahale, özellikle can ve mal kaybını önlemek için en önemli etkendir (URL 3). Uluslararası standartlara göre vakaya ulaşım süresi $5 \mathrm{dk}$ olarak belirlenmiştir. Bu doğrultuda, çalışmada kullanılan 387 adet 110 itfaiye çağrılarının, olay yerine ulaşım süreleri incelendiğinde; çağrı alındıktan sonra ortalama $2 \mathrm{dk}$. 'lık bir hazırlanma süresi ön görülmüștür. İtfaiye istasyonunun hizmet alanı için ortalama 45km/sa hızla ulaşılabilecek $5 \mathrm{dk}$. ve $10 \mathrm{dk}$.'lık mesafeler buffer alanları ile incelendiğinde; 110 itfaiye istasyonlarına ait $5 \mathrm{dk}$.'lık hizmet alanının, toplam çağrıların yaklaşık \%39 'unu kapsadığı, bu oranın $10 \mathrm{dk}$.'lık hizmet alanında incelendiğinde ise \%82 'ye yükseldiği görülmektedir. Literatürde yapılan çalışmalar ve yönetmelikler doğrultusunda yangın olaylarındaki ilk 5 dk.'nın önemi düşünüldüğünde \%39'luk bir kapsama alanının fazlasıyla yetersiz olduğu düşünülmektedir. Eski merkez mahallelerinin büyük kısmı hizmet alanı içinde yer alırken, merkeze bağlanan Ulalar, Kavakyolu, Çukurkuyu, Yalnızbağ, Demirkent, Akyazı ve Yaylabaşı'nın tamamen hizmet alanı dışında kaldığı tespit edilmiştir. Bu bölgelerin dışında cezaevi, Erzincan-Erzurum, Erzincan-Sivas ve Erzincan-Gümüşhane karayollarının da tamamının istasyon hizmet alanları dışında kaldığı görülmüștür. Yapılan çalışmalar incelendiğinde; Erden (2009) ve Erden ve Coşkun (2011) tarafından İstanbul ili içinde bulunan istasyonların uluslararası standart olan 5 dakika erişim zamanını sağlamadığı ve istasyonlar arası herhangi bir kesişim olmadığı belirlenmiş ve bu nedenle yerlerinin değiştirilmesinden ziyade yeni istasyonlar açılması önerisinde bulunulmuştur. Erzincan ili için gerçekleştirilen bu çalışma ile karşılaştırıldığında ise bu ilin bir adet istasyona sahip olması nedeniyle istasyonlar arası bir kesişimin söz konusu olmaması ve hizmet alanının da yeterli olmaması yeni istasyonların açılması gerekliliğini ortaya koymaktadır. İtfaiye istasyon yerlerinin kapsayıcılığının araştırıldığı diğer çalışmalarda da (Aydın, 2018; Chaudhary, vd., 2016) istasyon yerlerinin hizmet alanlarının oldukça düşük olduğu dikkat çekmektedir.

İtfaiye istasyonunun konumları ve 2018 yılında yapılan yangın çağrılarının değerlendirilmesi sonucunda; gerçekleşen yangınların İzzetpaşa mahallesi ve Yaylabaşı'nda yoğunlaştığı, İtfaiye istasyonunun konumu itibarı ile $5 \mathrm{dk}$.'llk hizmet alanı değerlendirildiğinde genel olarak merkez mahalleler için hizmet alanında sıkıntı görülmüyor olmasına rağmen merkeze yeni bağlanan 
beldeler ile bakıldığında fazlasıyla yetersiz olduğu tespit edilmiştir. Özellikle şehrin batı tarafındaki nüfus artışı ve kentleșme nedeniyle yaşanabilecek yangın vakalarında ulaşılabilirliğin zayıf olduğu görülmektedir. İzzetpaşa mahallesi ve diğer merkez mahallelerin gerçekleşen yangınlara 10dk.'lık müdahalelerin yeterli olduğu, buna karşın çağrıların yoğun geldiği bir diğer bölge olan Yaylabașı'nın hizmet alanının dıșında kaldığı görülmektedir.

Kavakyolu, Çukurkuyu, Yalnızbağ ve Demirkent'te nüfus ve kentleşmenin hızla arttığı, ayrıca bu bölgelerde halen eski köy yerleșiminden kalma ahır ve samanlık gibi yapıların bulunduğu ve bu bölgelerdeki binaların ısınma sistemlerinin halen katı yakıt ile çalıștığı bilinmektedir. Bunun neticesinde de yangınlarda artış yaşanacağı düșünülmektedir. Bu sebeple, Çukurkuyu ve Kavakyolu arasinda bulunan uygun bir arazisine yeni bir itfaiye istasyonu kurulması önerilmektedir. Yaylabaşı bölgesinden gelen çağrıların ise, yerleşim alanlarından daha çok Yaylabaşı kuzeyindeki Erzincan Belediyesi'ne ait katı atık depolamama alanından geldiği görülmektedir. Bu sebeple Yaylabaşı bölgesi mevcut istasyonun hizmet alanlarının dışında kalıyor olsa da bu bölgede yeni bir istasyon kurmak çok maliyetli ve gereksiz olacağından, katı atık depolama alanında çıkabilecek yangınlara erken müdahaleyi sağlamak ve gerektiğinde destek araçları gelene kadar yangını kontrol altında tutmak amacıyla, bir adet itfaiye aracı bulundurulması ya da uygun bir yangın söndürme sistemi kurulması ön görülmektedir.

İtfaiye verileri ile ilgili zaman grafiği incelendiğinde bazı haftalarda itfaiye çağrılarının maksimum düzeye ulaştığı görülmektedir. Bu durumda bazı haftalarda acil çağrılarda yoğunluk yaşandığı söylenebilir. Yapılan analizde verilerin durağan olmadığı görülmüş ve fark serisi alınarak model kurulmuştur. Sonuç olarak itfaiye verilerine ait zaman serisi modelinin ARIMA $(1,2,1)$ olduğu ve Box-Ljung testi sonuçlarına göre uygun bir model elde edildiği sonucuna ulaşılmıştır. Tahmin edilen modelin açıklayıcılığının ise R2 $=0.30$ olduğu görülmüştür. Zaman serileri analizinde tahmin edilen model ARIMA $(1,2,1)$ Yapay Sinir ağları ile de değerlendirilmiş ve iki farklı yöntem karşılaştırılmıştır. YSA yöntemine göre model incelendiğinde eğitim setinde R2 $=0.53$ olduğu modelin tamamında ise R2 $=0.51$ olduğu bulunmuştur. Bu durumda YSA yönteminin ZSA klasik yönteme göre daha başarılı olduğu anlaşılmıştır. Bu sonuçlardan hareketle YSA yöntemine göre itfaiye çağrılarında gelecekte bir artış gözlemlenebileceği sonucuna ulaşılmıştır.

Sonuç olarak CBS ile bakıldığında itfaiye istasyonunun konumu itibarı ile 5 dk.'lık hizmet alanı değerlendirildiğinde genel olarak merkez mahalleler için hizmet alanında sıkıntı görülmüyor olmasına rağmen merkeze yeni bağlanan beldeler ile bakıldığında fazlasıyla yetersiz olduğu tespit edilmiştir. 10dk.'lık müdahalelerin ise yeterli olduğu, buna karşın çağrıların yoğun geldiği bazı bölgelerin hizmet alanının dışında kaldığı görülmektedir. YSA analizinden elde edilen bulgulara göre ise ileriki dönemlerde alınan acil çağrılarda artış olacağı beklenmektedir. Bu duruma, şehir yapısının dinamik olmasının, gelişmeye açık olmasının ve nüfusta bir artış meydana gelmesinin sebep olabileceği düşünülmektedir. Bu nedenle mevcut durumda yeni istasyonların kurulmasına azami bir gereklilik görülmese de gelecek zamanda gerekli hale geleceği ön görülmektedir. Bu çalışmada coğrafi bilgi sistemleri ile tespit edilen istasyon yerlerinin söz konusu gereksinimi karşılayacağı düşünülmektedir.

Erzincan ilinde yapılan bu çalışmada ve başka illerde yapılan diğer çalışmalarda itfaiye istasyonlarının büyük ölçüde hizmet alanlarının yetersiz olduğu dikkat çekmektedir. Bu nedenle şehirlerde bulunan belediyelerin, yeni istasyonların yerlerinin belirlenmesi için CBS yöntemini kullanmaları önerilmektedir.

\section{KAYNAKLAR}

Aksaraylı M. (2005). Coğrafi Bilgi Sistemi Tabanlı Acil Afet Yönetimi Sistemi: İzmir İli Uygulaması, Doktora Tezi, Dokuz Eylül Üniversitesi Sosyal Bilimler Enstitüsü, İzmir, Türkiye. 
Erzincan İli 110 Acil Çağrılarının Coğrafi Bilgi Sistemleri ve Farklı İstatistiksel Analiz Yöntemleri ile Değerlendirilmesi

Aydın, C. (2018). Makine öğrenmesi algoritmaları kullanılarak itfaiye istasyonu ihtiyacının sınıflandırılması. Avrupa Bilim ve Teknoloji Dergisi, 14, 169-175.

Bayata, H. F. (2010). Trafik kazalarının çok değişkenli istatistiksel yöntemlerle modellenmesi, Yayımlanmamış Doktora Tezi, Atatürk Üniversitesi Fen Bilimleri Enstitüsü, Erzurum.,184.

Bayata, H. F. ve Hattatoğlu, F. (2011). Erzincan ili için farklı yöntemlerle trafik kaza tahmin modellemesi. Erzincan Üniversitesi Fen Bilimleri Enstitüsü Dergisi, 4(1), 31-46.

Bozkurt, H. (2007). Zaman Serileri Analizi. Ekin Kitapevi, Bursa.

Chaudhary, P., Chhetri, S. K., Joshi, K. M., Shrestha, B. M. \& Kayastha, P. (2016). Application of an Analytic Hierarchy Process (AHP) in the GIS interface for suitable fire site selection: A case study from Kathmandu Metropolitan City, Nepal. Socio-Economic Planning Sciences, 53, 60-71.

Coşkun, N. (2007). Acil Servis Sistemlerinde Yerleşim Problemine Analitik ve Genetik Programlama Yaklaşımları, Yüksek Lisans Tezi, Çukurova Üniversitesi Fen Bilimleri Enstitüsü, Adana, Türkiye.

Djokanovic, S., Abolmasov, B. \& Jevremovic, D. (2016). GIS application for landfill site selection: a case study in Pancevo, Serbia. Bulletin of Engineering Geology and the Environment, 75, 1273-1299.

Erden, T. (2009). Coğrafi Bilgi Sistemleri ile Analitik Hiyerarşi Yöntemi’ne Dayalı İtfaiye İstasyon Yer Seçimi: İstanbul Örneği, Doktora Tezi, İstanbul Teknik Üniversitesi Fen Bilimleri Enstitüsü, İstanbul, Türkiye.

Erden, T. ve Coşkun, M. Z. (2011). Coğrafi bilgi sistemleri ve analitik hiyerarşi yöntemi yardımıyla itfaiye istasyon yer seçimi, TMMOB Harita ve Kadastro Mühendisleri Odası 13. Türkiye Harita Bilimsel ve Teknik Kurultayı, Ankara.

Erkal, T. ve Değerliyurt, M. (2013). Eskişehir'de acil durum yönetiminde ağ (network) analizlerinin kullanılması. Türk Coğrafya Dergisi, 61, 11-20.

Eroğlu, H. (2014). Coğrafi bilgi sistemleri (cbs) ve bulanık analitik hiyerarşi metodu (fahp) kullanılarak rüzgar santralleri için en uygun yer tayini. Elektrik - Elektronik - Bilgisayar ve Biyomedikal Mühendisliği Sempozyumu, Bursa.

Küpçü, S. (2005). ArcGıs 9 Uygulama Dökümanı, Ankara: Sinan Ofset Matbaacılık.

Nișancı R., Yıldırım V. ve Erbaș Y. S. (2012) "Fire analysis and production of fire risk maps: the trabzon experience, risk management for the future-theory and cases", Risk Management for the Future - Theory and Cases (Edited by Dr Jan Emblemsvåg), 215-232.

Öztürk, Y. E., Öncel, H. ve Ördek, E., (2013). Konya-Selçuklu ilçesinde 112 acil servis istasyonları yerleşim modeli Selçuk Üniversitesi Mühendislik Bilim ve Teknoloji Dergisi, 1(1), 19-32.

Uslu, A., Kızıloğlu, K., İşleyen, S. K. ve Kahya, E. (2017). Okul yeri seçiminde coğrafi bilgi sistemine dayalı AHP-TOPSIS yaklaşımı: Ankara ili örneği. Politeknik Dergisi, 20(4), 933-943.

Pasha, I. (2006). Ambulance Management System Using GIS, Master Thesis, Department of Computer and Information Science Linköping University, Sweden,

ReVelle C.S. \& Eiselt H.A. (2005). Location analysis: a synthesis and survey. European Journal of Operational Research, 165(1), 1-19.

Sarhan R. S., Shabana B. T. \& El-Bakry, H. M. (2015). Design of an efficient integrated system for ambulance management. International Journal of Electronics Communication and Computer Engineering, 6(4), 22784209. 
Selim, H. ve Özkarahan, İ., (2003). Acil servis araçları yerleşiminin belirlenmesinde yeni bir model. Endüstri Mühendisliği Dergisi, 14 (1), 18-27.

Solak, A. O. (2013). Türkiye'nin toplam petrol talebi ve ulaştırma sektörü petrol talebinin arıma modeli ile tahmin edilmesi. Süleyman Demirel Üniversitesi İktisadi ve İdari Bilimler Fakültesi Dergisi, 18(3), s.131142.

Swalehe, M. (2016). Dynamic Ambulance Deployment to Reduce Ambulance Response Times Using Geographic Information Systems: A Case Study of Odunpazarı District of Eskişehir Province, Republic of Turkey, Master Thesis, Anadolu University, Eskişehir, Turkey.

Tarı R. (2008). Ekonometri, Kocaeli Ünv. Yayınları, Avcı Ofset, İstanbul.

URL 1, https://www.erzincan.bel.tr/mudurlukyazi/46/\%C4\%B0\%C5\%9E\%20AKI\%C5\%9E\%20SEMASI (Son Erişim: 15.06.2019)

URL 2, https://www.nufusu.com/il/erzincan-nufusu (Son erişim: 15.06.2019)

URL 3, http://www.nfpa.org/ (Son Erişim: 05.06.2019)

Yalçın, M. ve Batuk, F. (2010). Toplu konut alanlarının CBS-çok ölçütlü karar verme yöntemiyle belirlenmesi: Bakırköy ilçesi. III. Uzaktan Algılama ve Coğrafi Bilgi Sistemleri Sempozyumu, 10, 579-585. 